Article

\title{
Epiphytic Cryptogams as Bioindicators of Air Quality in a Tropical Andean City
}

\author{
Juan Díaz ${ }^{\dagger}$, Luis Montaño, Paul Salinas and Ángel Benítez ${ }^{*}++^{+}$ \\ Departamento de Ciencias Biológicas y Agropecuarias, Universidad Técnica Particular de Loja, San Cayetano s/n, \\ Loja 1101608, Ecuador; sebas_d_90@hotmail.com (J.D.); luis46vr58@gmail.com (L.M.); \\ paulsalinasforestal@hotmail.com (P.S.) \\ * Correspondence: arbenitez@utpl.edu.ec \\ + Co-first author, these authors contributed equally to this work.
}

check for updates

Citation: Díaz, J.; Montaño, L.; Salinas, P.; Benítez, Á. Epiphytic Cryptogams as Bioindicators of Air Quality in a Tropical Andean City. Sustainability 2021, 13, 11218. https:// doi.org/10.3390/su132011218

Academic Editor: Alessandra De Marco

Received: 14 July 2021

Accepted: 18 September 2021

Published: 12 October 2021

Publisher's Note: MDPI stays neutral with regard to jurisdictional claims in published maps and institutional affiliations.

Copyright: (C) 2021 by the authors Licensee MDPI, Basel, Switzerland. This article is an open access article distributed under the terms and conditions of the Creative Commons Attribution (CC BY) license (https:/ / creativecommons.org/licenses/by/ $4.0 /)$.

\begin{abstract}
Air pollution is one of the main environmental problems in developed and developing countries. Epiphytic cryptogams (bryophytes and lichens) are proposed as a reliable indicator to detect environmental changes, given to their sensitivity to pollutants. In this study we evaluated air quality in the city of Ambato using bryophytes and epiphytic lichens on three land uses (urban, peri-urban and control). In each zone we selected ten trees (a total of 90 trees) for each station (a total of nine stations), where we recorded the frequency and cover of epiphytic cryptogams in a quadrat of $10 \times 50 \mathrm{~cm}$ that was divided into $5 \times 5 \mathrm{~cm}$ squares. Differences in richness, index of atmospheric purity (IAP) and diversity were analyzed using a generalized linear model (GLM) and changes in species composition using multivariate analysis. We recorded 39 species of cryptogams (25 lichens and 14 bryophytes). Richness, diversity and index of atmospheric purity were higher in the control zone compared to the urbanized zones. Community composition changed between the different zones, with increasing differences between the control and urban zones. The urban areas of the city of Ambato were identified with high levels of air pollution due to their lower diversity related to higher vehicular traffic and industrial activities (e.g., footwear and textile factories, tanneries). Thus, epiphytic cryptogams are a fast and low-cost method for air quality assessment in tropical areas.
\end{abstract}

Keywords: alpha diversity; beta diversity; bryophytes; Ecuador; lichens

\section{Introduction}

Air pollution is currently one of the main environmental problems in urban and rural areas due to rapidly developing industrialization and urbanization worldwide as well as in Latin American cities [1-4]. Vehicular traffic and industrial activities in emerging economies deteriorate the air quality in large areas where there is no air pollution monitoring network [5], and thus chronic and acute exposures of inhaled pollutants can produce toxic effects in biological systems [6].

Ambato is a city located in the central Andean valley of Ecuador and one the most important cities in terms of productivity (e.g., industrial, commercial and manufacturing engine) and economy at the regional level [7]. Thus, industrial activities (e.g., footwear and textile factories, tanneries) lead to a constant growth in the flow of different types of motorized transport that generate high levels of air pollution [8]. The expansion of the urban areas towards rural areas implies the elimination of green areas, generating environmental impacts in the city, and therefore air pollution becomes one of the main environmental problems [8]. Thus, in the city has carried out evaluations of certain pollutants as sulfur dioxide $\left(\mathrm{SO}_{2}\right)$, nitrogen dioxide $\left(\mathrm{NO}_{2}\right)$ ozone $\left(\mathrm{O}_{2}\right)$, benzene $\left(\mathrm{C}_{6} \mathrm{H}_{6}\right)$ [8], carbon dioxide $\left(\mathrm{CO}_{2}\right)$ and sulfur oxides $\left(\mathrm{SO}_{\mathrm{x}}\right)$ related with air pollution. However, there is only one air pollution monitoring station and few studies in this city, which has not made possible the accurate determination of the current state of the air quality in the different zones of city of Ambato [9]. 
Epiphytic cryptogams, due to their anatomical, morphological, and physiological characteristics (e.g., they obtain nutrients directly from the atmosphere) [10], are very effective as bioindicators of air pollution in many cities around the world [11-20], and also for programs and protocols of air pollution in several countries. These organisms allow early detection of signs of environmental change given that they are fully exposed to airborne contaminants $[11,16,21]$. Thus, the application of epiphytic cryptogams are a fast and low-cost method for this purpose.

The Index of Atmospheric Purity (IAP) has been a commonly used tool to determine air quality using lichens and bryophytes [16]; however, more studies have been in temperate zones [22-25] than tropical ones $[16,26,27]$. Previous studies found that higher IAP values had shown better air quality [28-32]. Conversely, low IAP values are related with reduction of the most sensitive species, indicating higher degrees of air pollution [14,16,32]. Thus, studies in tropical areas have documented that urban areas have high levels of air pollutant related with vehicular traffic and industrial activities than areas far from the city [11,14,16,30,33-37].

Studies in Ecuador using bioindicators to detect air pollution are scarce [3,32,37]. Thus, for the first time, epiphytic cryptogams (lichens and bryophytes) were used as biomonitors to assess the air pollution in the city of Ambato. Specifically, we addressed the following questions: (1) Are the richness, IAP and composition of cryptogams (lichens and bryophytes) influenced by land use changes? and (2) Can cryptogams (lichens and bryophytes) be used as indicators of air pollution related to vehicular traffic?

\section{Materials and Methods}

\subsection{Study Area}

The present study was carried out at nine stations of the city of Ambato (Figure 1), in the western mountain cordillera of Ecuador, at $2678 \mathrm{~m}$ a.s.l. with an approximate area of $1016.454 \mathrm{~km}^{2}$ and temperature that fluctuates between 12 and $27^{\circ} \mathrm{C}$. Nine sampling stations located in three land uses (three urban stations, three peri-urban stations and three control stations) were selected.
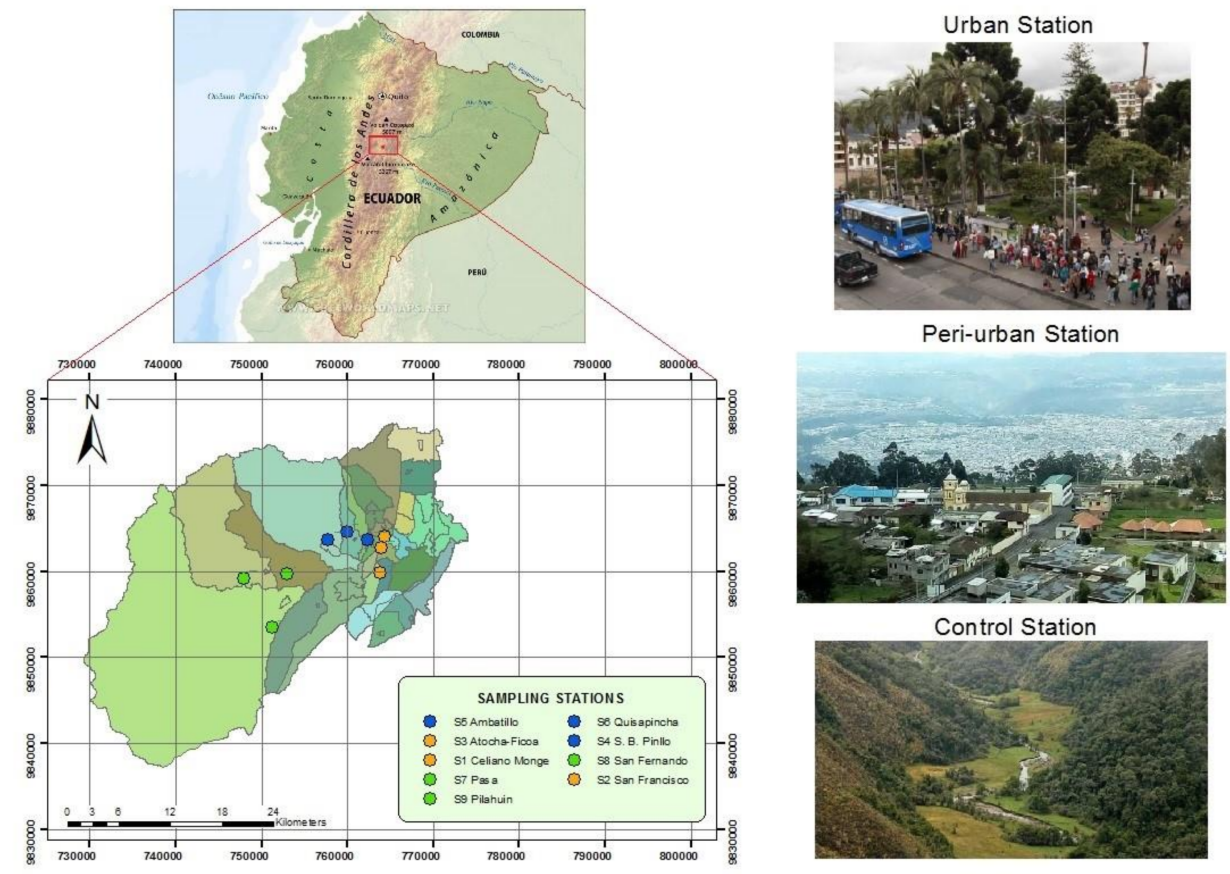

Figure 1. Sampling stations in the city of Ambato. $\mathrm{S} 1=$ Celiano Monge, $\mathrm{S} 2=\mathrm{San}$ Francisco, S3 = AT = Atocha-Ficoa, S4 = SB Pinllo, S5 = Ambatillo, S6 = Quisapincha, S7 = Pasa, S8 = San Fernando and S9 = Pilahuin. 
The control zone (Figure 1) was located in the high areas of the rustic parishes of Ambato, represented by a dense canopy layer of evergreen montane tropical vegetation (e.g., Alnus acuminata) and very little rural traffic (3 vehicles/h). The peri-urban zone (Figure 1) was located on the periphery of the city with an accelerated advancement of the agricultural frontier, where the disturbed forests are mixed with pastures dominated by planted trees of Eucalyptus globulus; and is subject to relative high levels of traffic (1000 vehicles/h) due to the transit between this area and the city. The urban zone (Figure 1) was located within the central area. This part of the city has a very uniform structure and is dominated by a section of grassland with planted trees of introduced species and palms. This area has higher levels of vehicular traffic (2080 vehicles/h) and industrial and commercial activities than the others. The research was conducted during the months of March to September 2020.

\subsection{Design and Data Collection}

Three stations were selected for each land use (a total of nine stations), 10 trees with similar bark structure and diameter at breast height $(\mathrm{DBH})>10 \mathrm{~cm}$ were chosen for each station (90 trees). In each tree, the frequency and cover of bryophytes and epiphytic lichens were recorded with a $10 \times 50 \mathrm{~cm}$ quadrat that was divided into 20 squares of $5 \times 5 \mathrm{~cm}[30,32]$, which was placed vertically at $1.20 \mathrm{~m}$.

We obtained vehicular traffic with punctual one-day sampling data related with the number of vehicles for each zone. We considered three different categories: $(\mathrm{LV})=$ light-vehicles: cars and small vans; $(\mathrm{HV})=$ heavy-vehicles: trucks and buses; and (MT) = motorbikes [38].

The specimens were identified using general and specific taxonomic keys for bryophytes [39-41] and lichens [42-45]. Specimens were deposited in the herbarium of the Universidad Técnica Particular de Loja (HUTPL) and were collected with authorization for scientific research No. 02-2020-IC-FLO-DPAT-VS and moved under the wildlife specimens mobilization act No. 17-2020-DPAT-V.S.

\subsection{Data Analysis}

In order to determine the sampling effort in the three zones, a species accumulation curve based on samples and the Chao 2 nonparametric richness estimator was used. Species richness and diversity (Shannon-Weaver and Simpson indices) were determined. The Index of Atmospheric Purity (IAP) was used to determine air quality in the city of Ambato. The IAP was calculated based on the summary of the frequencies of all the species present in each sampled tree [30].

IAP tree $=$ Summary of the frequency of each species. Values from 0 to 20.

IAP area $=$ Average IAP values of trees for each area.

Box plots were used to visualize changes in richness, diversity, and index of atmospheric purity in the different zones. Changes in richness, diversity, and the index of atmospheric purity of epiphytic cryptogams related with land use and station were analyzed with generalized linear models (GLM), using a Poisson error distribution and a logarithmic link function [46]. We applied non-parametric correlations (Spearman, $p<0.05$ ) between richness, IAP, diversity and vehicular traffic.

Non-metric multidimensional scaling (NMDS) was performed to detect patterns of species composition in relation to land uses. The NMDS was run using the Bray-Curtis distance and 999 Monte Carlo permutations. To test whether the three land uses had significantly different compositions of epiphytic cryptogams and to detect the effects of station and vehicular traffic, we performed a permutational multivariate analysis of variance (PERMANOVA). All analyses were performed with $\mathrm{R}$ statistical software version 3.6.3 [47] and the statistical package "vegan" [48].

\section{Results}

\subsection{Alfa Diversity}

A total of 39 epiphytic cryptogams (25 lichens and 14 bryophytes) were identified in the 90 sampled trees, distributed in 22 families and 29 genera (Appendix A). The accumulation 
curves and Chao 2 richness estimator showed high values of estimated species for the control area with $39 \pm 6.17$, follow peri-urban and urban zones with $16 \pm 0.48$ and $8 \pm 0.96$, respectively (Figure 2).

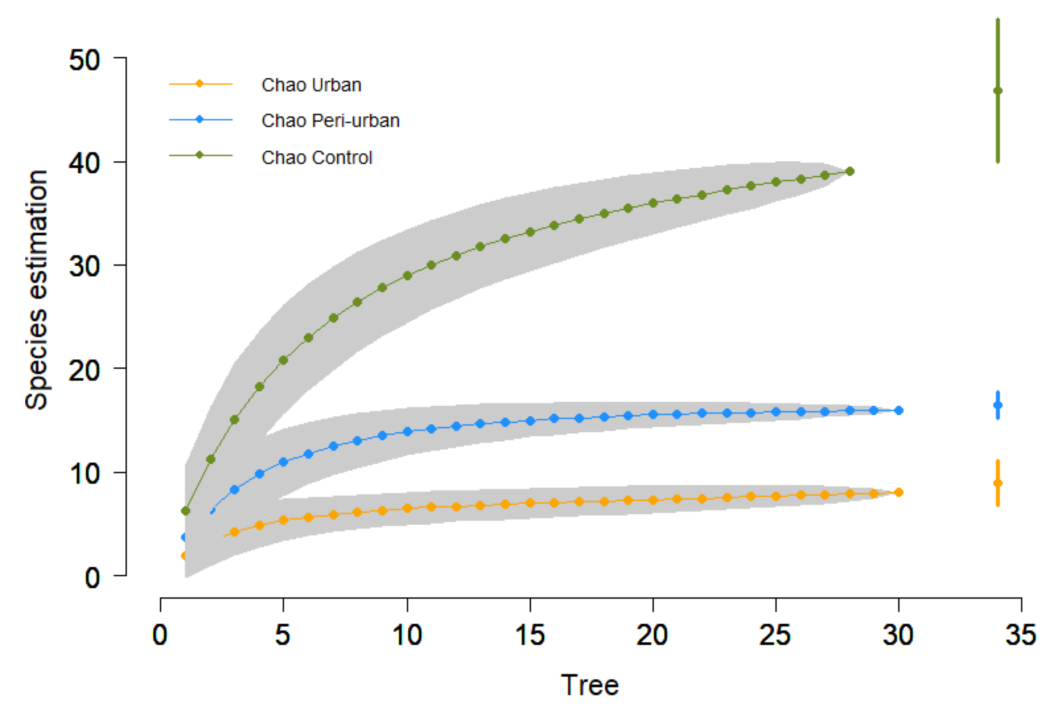

Figure 2. Species rarefaction curve with 95\% confidence interval and Chao 2 estimator for three land uses (Control, Peri-urban and Urban).

Species richness at tree level showed a high value for the control zone (14) compared with the peri-urban (9) and urban (5) zones (Figure 3). The mean value of the ShannonWeaver index was 1.50 for the control zone, 1.10 and 0.70 for the peri-urban and urban zones, respectively (Figure 3). A similar pattern was observed for Simpson's index, with high values for the control zone ( 0.70 control zone, 0.62 peri-urban zone and 0.45 urban zone). The IAP showed high values for control and peri-urban zones (Figure 3 ). On the other hand, IAP by zone showed high values for the control zone with 75.7, followed by the peri-urban and urban zones with 67.76 and 44.66 , respectively.
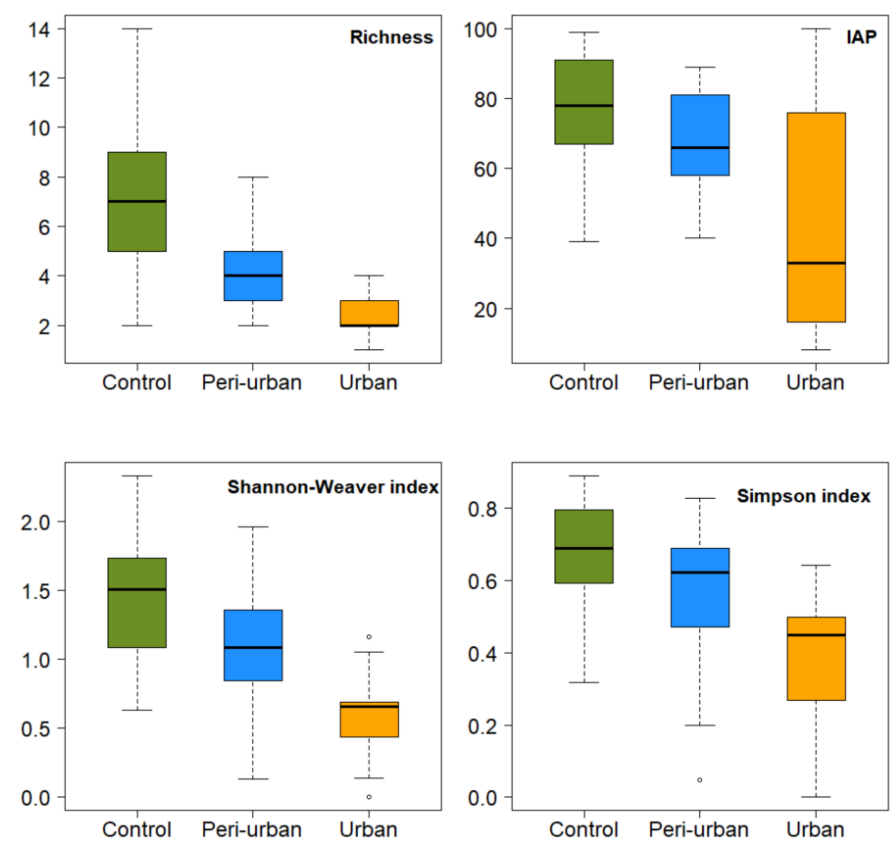

Figure 3. Box and whisker plots of species richness, IAP (Index of Atmospheric Purity) ShannonWeaver and Simpson index between urban, peri-urban and control areas.

Richness, species diversity and index of atmospheric purity were influenced by zone, where the control zone has a positive effect and the peri-urban and urban zones have a 
negative effect (Table 1). A similar pattern was observed at the station level, with a positive effect at the stations in the control zone (Table 1).

Table 1. Results of the Generalized Linear Model between richness, index of atmospheric purity and diversity of epiphytic cryptogams as a function of the different land uses and station. S1 = Celiano Monge, S2 = San Francisco, S3 = Atocha-Ficoa, S4 = SB Pinllo, S5 = Ambatillo, S6 = Quisapincha, S7 = Pasa, S8 = San Fernando and S9 = Pilahuin.

\begin{tabular}{ccccccccc}
\hline & \multicolumn{2}{c}{ Richness } & \multicolumn{2}{c}{$\begin{array}{c}\text { Index of Atmospheric } \\
\text { Purity }\end{array}$} & \multicolumn{2}{c}{ Shannon-Weaver Index } & Simpson Index \\
& Estimate & $p$ Value & Estimate & $p$ Value & Estimate & $p$ Value & Estimate & $p$ Value \\
\hline Control & 1.8245 & $<0.0001$ & 4.18358 & $<0.0001$ & 1.3274 & $<0.0001$ & 0.6523 & $<0.0001$ \\
Peri-urban & -0.7691 & $<0.0001$ & -0.22552 & $<0.0001$ & -0.3486 & 0.0212 & -0.0190 & $<0.0001$ \\
Urban & -0.7598 & 0.0007 & 0.25908 & $<0.0001$ & -0.8322 & $<0.0001$ & -0.3651 & $<0.0001$ \\
S5 & 0.1973 & 0.4939 & 0.27895 & 0.0002 & -0.3047 & 0.1501 & -0.2654 & 0.0067 \\
S1 & -0.2662 & 0.3597 & -1.5647 & $<0.0001$ & 0.1188 & 0.4378 & 0.1159 & 0.0980 \\
S7 & 0.2796 & 0.0967 & 0.24962 & $<0.0001$ & 0.1109 & 0.4565 & -0.0138 & 0.8384 \\
S9 & 0.1633 & 0.3443 & 0.19344 & 0.0002 & 0.2053 & 0.17 & 0.0586 & 0.3870 \\
S6 & 0.8009 & 0.0025 & 0.26586 & 0.0004 & 0.5401 & 0.0118 & 0.0904 & 0.3458 \\
S2 & -0.1304 & 0.6226 & -1.02642 & $<0.0001$ & 0.1948 & 0.1826 & 0.1428 & 0.03301 \\
\hline
\end{tabular}

Following this pattern, the results of Spearman correlations showed a strong negative correlation between richness ( $\mathrm{r}=-0.71, p$-value $<0.0001)$, IAP $(\mathrm{r}=-0.51, p$-value $<0.0001)$, the Shannon-Weaver index $(\mathrm{r}=-0.64, p$-value $<0.0001), \mathrm{r}=-0.55, p$-value $<0.0001)$ and vehicular traffic.

\subsection{Beta Diversity}

The NMDS ordination showed that the community composition of epiphytic cryptogams (lichen and bryophyte) is different in the in urban areas compared to the control areas (Figure 4).

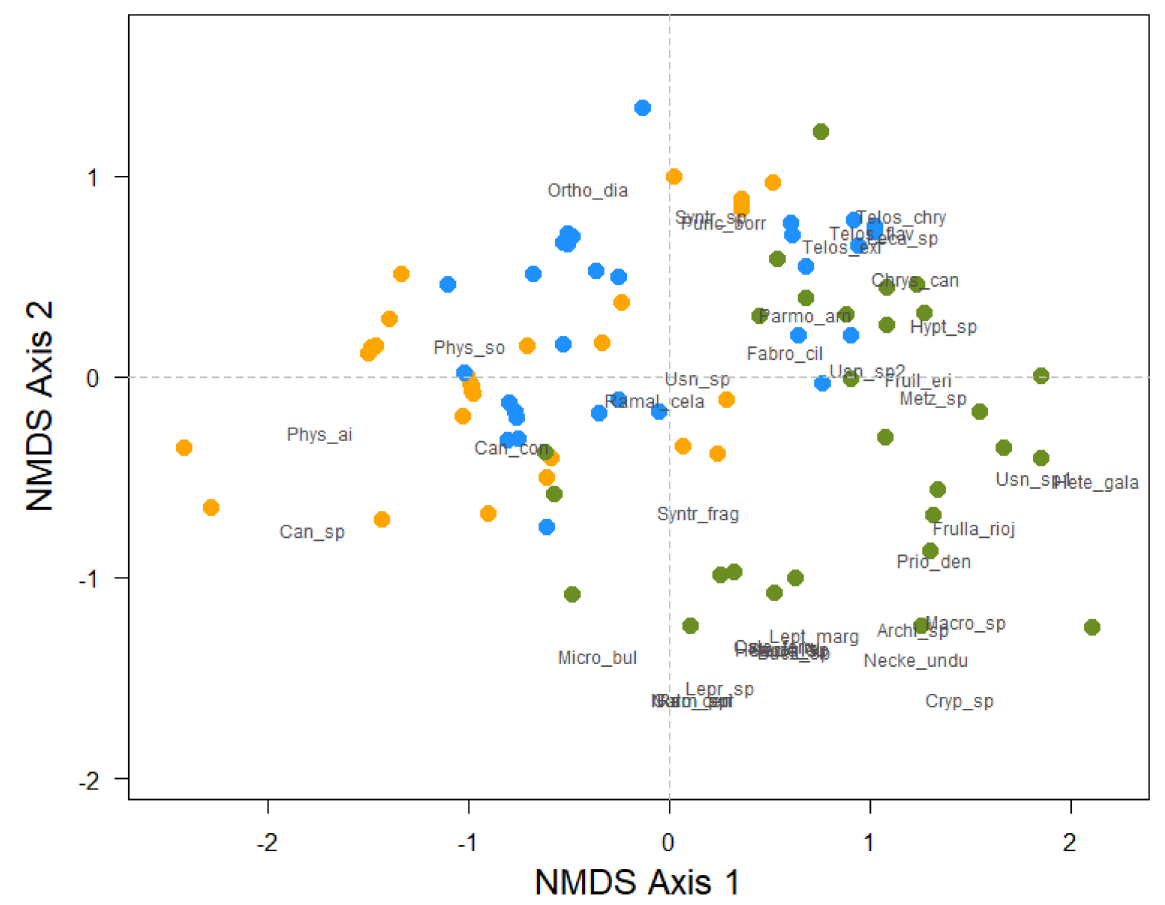

Figure 4. Non-metric multidimensional scaling analysis (NMDS) of the species composition in the three land uses. Urban zone $=$ orange dots, peri-urban zone = blue dots and control zone = green dots.

The multivariate statistical analyses showed that epiphytic composition of cryptogams was structured according to land use changes, with a large component of variation (i.e., 
$30 \%$ ) associated with station, followed by zone and vehicular traffic, with $15 \%$ and $12 \%$, respectively (Table 2 ).

Table 2. PERMANOVA results of species composition at the zone and station level. Df = degrees of freedom; SS = sum of squares; MS = median squares, F = F-statistics; $\mathrm{R}^{2}=$ coefficient of variation.

\begin{tabular}{ccccccc}
\hline Factor & Df & SS & MS & F & $\mathbf{R}^{2}$ & $p$ Value \\
\hline Station & 5 & 10.053 & 2.0106 & 12.01 & 0.3087 & 0.001 \\
Vehicular & 1 & 3.911 & 3.9111 & 23.36 & 0.1201 & 0.001 \\
traffic & 2 & 5.038 & 2.5188 & 15.04 & 0.1547 & 0.001 \\
Zone & 81 & 13.563 & 0.1674 & & 0.4165 & \\
Residuals & 89 & 32.564 & & & 1 & \\
Total & 89 & & & &
\end{tabular}

\section{Discussion}

The results indicated changes in the diversity (alpha and beta) and the index of atmospheric purity of epiphytic cryptogam communities as moving from rural (control) to urban areas. Similarly, previous studies found that diversity and IAP decreases in urban areas as a result of land use, industrial activity and increase in the flow of different types of motorized transport that generate a greater amount of polluting emissions [15,26,32,49].

In this context, the index of atmospheric purity, richness, and diversity (ShannonWeaver and Simpson diversity indices) showed a significant increase in the control zone, indicating better air quality, as reported in previous studies $[14,26,28,50,51]$. In addition, in the control zone there was a higher richness of species sensitive to contamination (e.g., Neckeropsis undulata) and lichen species (e.g., Leptogium marginellum). An opposite pattern was observed in the urban area, with low diversity and IAP values related to higher pollution, mainly due to the vehicle fleet and industrial activities in urban zones $[26,27,29,30]$ and the dominance of species resistant to atmospheric pollution, such as Candelaria concolor, Physcia sorediosa and Physcia aipolia.

Following the same pattern, the composition of the cryptogam communities revealed significant changes between control and urban zones. Control zones were dominated by bryophyte species (e.g., Neckeropsis undulata and Syntrichia fragilis) and some sensitive lichen species (e.g., Teloschistes chrysophthalmus) that were classified as sensitive to contamination in previous studies $[16,26]$. Conversely, in urban areas there is a greater coverage of tolerant species, such as Candelaria concolor and Physcia aipolia that are closely related to increased vehicular traffic and industrial activities. Supporting this idea, several studies have documented that these species are characteristic of areas with a high degree of pollution $[16,26,32]$.

However, the Atocha-Ficoa urban station showed IAP values and community composition very similar to the control station, which may be related to vegetation cover (nine hectares) with a high diversity of tree species (Cedrela odorata L. and Jubaea chilensis Baill). Similarly to our results, previous studies have shown that urban areas with large vegetation coverage and native wooded species imply more habitat available for the establishment of epiphytic cryptogams [32]. Thus, it is important to consider that changes in diversity, IAP, and community composition in the epiphytic cryptogam communities in the city of Ambato also occurred at the station level.

Although our study demonstrates the efficacy of cryptogam diversity in biomonitoring of land use changes and air quality in the city of Ambato, we suggest that future work should evaluate the effects of microclimatic changes and host tree traits in epiphytic cryptogams as part of biomonitoring, given that previous studies have shown that urbanization related with microclimatic changes (e.g., canopy cover), host tree traits including bark texture, $\mathrm{pH}$, and tree diameter show significative effects on cryptogam diversity in tropical urban environments [52-54]. 


\section{Conclusions}

In conclusion, the index of atmospheric purity, alpha and beta diversity of epiphytic cryptogams were drastically affected by changes in land use (e.g., urbanization), related to increased vehicular traffic and industrial activities (e.g., footwear, tanneries, textile). The urban area of the city of Ambato was identified as having high levels of air pollution due to its high vehicular traffic, low diversity and IAP values. This work showed that epiphytic cryptogams are suitable for monitoring air pollution in Ecuador, and that the combined use of alpha, beta diversity and index of atmospheric purity with epiphytic cryptogams proved to be a fast and low-cost effective method for air quality assessment in tropical areas.

Author Contributions: Conceptualization, Á.B. and J.D.; methodology, Á.B. and J.D.; formal analysis, Á.B. and J.D.; investigation, Á.B. and J.D.; writing-original draft preparation, Á.B., J.D., P.S. and L.M.; writing-review and editing, Á.B., J.D. and L.M. All authors have read and agreed to the published version of the manuscript.

Funding: This research was funded by Universidad Técnica Particular de Loja (UTPL-PROY_INV_CCBIO_ 2020_2773).

Institutional Review Board Statement: Not applicable.

Informed Consent Statement: Not applicable.

Data Availability Statement: Data is contained within the article.

Acknowledgments: We thank Ministerio del Ambiente y Agua del Ecuador by providing access to the study areas and anonymous reviewers for constructive comments on the manuscript.

Conflicts of Interest: The authors declare no conflict of interest.

\section{Appendix A}

Table A1. Stations on which each species appears. S1-3 = Urban station; S4-6 = Peri-urban station and S7-9 = Control station. S1 = Celiano Monge, S2 = San Francisco, S3 = AT = Atocha-Ficoa, S4 = SB Pinllo, S5 = Ambatillo, S6 = Quisapincha, S7 = Pasa, S8 = San Fernando and S9 = Pilahuin.

\begin{tabular}{|c|c|c|c|c|c|c|c|c|c|c|}
\hline Taxa & Code & S1 & S2 & S3 & $\mathrm{S} 4$ & S5 & S6 & S7 & S8 & S9 \\
\hline Bryophytes & & \multicolumn{9}{|c|}{ Coverage $\%$} \\
\hline Archilejeunea sp. & Arch_sp & - & - & - & - & - & - & - & 0.80 & 0.90 \\
\hline Cryphaea sp. & Cryp_sp & - & - & - & - & - & - & - & 0.40 & - \\
\hline $\begin{array}{l}\text { Fabronia ciliaris } \\
\text { (Brid.) Brid. }\end{array}$ & Fabr_cil & - & - & - & 0.10 & - & 1.40 & - & - & 0.70 \\
\hline $\begin{array}{c}\text { Frullania ericoides } \\
\text { (Nees) Mont. } \\
\text { Frullania }\end{array}$ & Frulla_eri & - & - & - & - & - & 1.90 & 0.90 & 2.80 & - \\
\hline $\begin{array}{l}\text { riojaneirensis (Raddi) } \\
\text { Spruce }\end{array}$ & Frulla_rio & - & - & - & - & - & - & - & 2.70 & - \\
\hline Macromitrium sp. & Macro_sp & - & - & - & - & - & - & - & 5.00 & 6.20 \\
\hline Metzgeria sp. & Metz_sp & - & - & - & - & - & - & 0.30 & 0.50 & 0.10 \\
\hline $\begin{array}{l}\text { Microlejeunea bullata } \\
\text { (Taylor) Steph. }\end{array}$ & Micro_bu & - & - & - & - & - & - & - & - & 8.80 \\
\hline $\begin{array}{l}\text { Neckeropsis undulata } \\
\text { (Hedw.) Reichardt } \\
\text { Orthotrichum }\end{array}$ & Necke_undu & - & - & - & - & - & - & - & 2.40 & 5.30 \\
\hline $\begin{array}{c}\text { diaphanum Schrad. } \\
\text { ex Brid. }\end{array}$ & Ortho_dia & - & - & - & 18.90 & - & 1.00 & 0.80 & - & 1.50 \\
\hline $\begin{array}{l}\text { Prionodon densus } \\
\text { (Sw. ex Hedw.) } \\
\text { Müll. Hal. }\end{array}$ & Prio_den & - & - & - & - & - & - & 0.10 & 0.30 & - \\
\hline Sematophyllum sp. & Sema_sp & - & - & - & - & - & - & - & - & 2.20 \\
\hline $\begin{array}{l}\text { Syntrichia fragilis } \\
\text { (Taylor) Ochyra }\end{array}$ & Syntr_fra & - & 2.80 & 2.40 & - & 0.10 & 2.60 & 2.20 & 5.80 & 15.90 \\
\hline Syntrichia sp. & Syntr_sp & - & - & 8.30 & 5.40 & - & 3.50 & 2.40 & 0.10 & - \\
\hline
\end{tabular}


Table A1. Cont.

\begin{tabular}{|c|c|c|c|c|c|c|c|c|c|c|}
\hline Taxa & Code & $\mathrm{S} 1$ & S2 & S3 & $\mathrm{S} 4$ & S5 & S6 & S7 & S8 & S9 \\
\hline \multicolumn{11}{|l|}{ Lichens } \\
\hline Buellia sp. & Buell_sp & - & - & - & - & - & - & - & 0.10 & 1.40 \\
\hline $\begin{array}{l}\text { Candelaria concolor } \\
\text { (Dicks.) Arnold }\end{array}$ & Can_col & 5.40 & 8.90 & 0.20 & 1.50 & 47.10 & - & - & - & 18.90 \\
\hline $\begin{array}{l}\text { Candelaria sp. } \\
\text { Caloplaca aff. }\end{array}$ & Can_sp & - & - & 2.60 & - & - & - & - & - & 1.50 \\
\hline $\begin{array}{c}\text { ferruginea (Huds.) } \\
\text { Th.Fr. }\end{array}$ & Calo_ferr & - & - & - & - & - & - & - & - & 2.90 \\
\hline $\begin{array}{l}\text { Caloplaca sp. } \\
\text { Chrysothrix }\end{array}$ & Calo_sp & - & - & - & - & - & - & - & - & 2.10 \\
\hline $\begin{array}{l}\text { candelaris (L.) J. R. } \\
\text { Laundon }\end{array}$ & Chry_can & - & - & - & - & - & - & 2.50 & - & - \\
\hline $\begin{array}{c}\text { Heterodermia } \\
\text { galactophylla (Tuck.) } \\
\text { W.L.Culb. }\end{array}$ & Het_gala & - & - & - & - & - & - & - & 0.10 & - \\
\hline Hypotrachyna sp. & Hyp_sp & - & - & - & - & - & - & 3.50 & 1.70 & - \\
\hline Lecanora sp. & Leca_sp & - & - & - & - & - & 2.80 & 2.70 & 0.10 & - \\
\hline $\begin{array}{l}\text { Lepraria sp. } \\
\text { Leptogium }\end{array}$ & Lepr_sp & - & - & - & - & - & - & - & - & 0.90 \\
\hline $\begin{array}{l}\text { marginellum (Sw.) } \\
\text { Gray }\end{array}$ & Lept_mar & - & - & - & - & - & - & - & - & 0.10 \\
\hline $\begin{array}{l}\text { Leucodermia } \\
\text { leucomelos (L.) Kalb } \\
\text { Normandina }\end{array}$ & Leu_leuco & - & - & - & - & - & - & - & - & 0.40 \\
\hline $\begin{array}{l}\text { pulchella (Borrer) } \\
\text { Nyl. }\end{array}$ & Norm_pul & - & - & - & - & - & - & - & - & 0.10 \\
\hline $\begin{array}{l}\text { Parmotrema arnoldii } \\
\text { (Du Rietz) Hale }\end{array}$ & Parm_arn & 0.20 & - & 39.50 & - & 0.80 & 12.30 & 16.30 & 9.50 & 5.40 \\
\hline $\begin{array}{l}\text { Physcia aipolia (Ehrh. } \\
\text { ex Humb.) Fürnr. }\end{array}$ & Phys_aip & 0.10 & 6.20 & 12.70 & 1.60 & - & - & - & - & 0.80 \\
\hline $\begin{array}{l}\text { Physcia sorediosa } \\
\text { (Vain.) Lynge }\end{array}$ & Phys_sor & 13.10 & 12.30 & 0.60 & 21.40 & 17.10 & - & - & - & 2.60 \\
\hline $\begin{array}{l}\text { Punctelia borreri } \\
\text { (Sm.) Krog }\end{array}$ & Punc_borr & 0.50 & - & 18.20 & 16.90 & 1.00 & 24.30 & 39.00 & 1.60 & - \\
\hline $\begin{array}{l}\text { Ramalina celastri } \\
\text { (Spreng.) Krog \& } \\
\text { Swinscow }\end{array}$ & Ramal_cel & - & - & - & - & 2.10 & - & 1.80 & 1.50 & - \\
\hline $\begin{array}{l}\text { Ramalina sp. } \\
\text { Teloschistes }\end{array}$ & Ramal_sp & - & - & - & - & - & - & - & - & 0.10 \\
\hline $\begin{array}{l}\text { chrysophthalmus (L.) } \\
\text { Beltr. }\end{array}$ & Telos_chry & - & - & - & - & - & - & 2.20 & - & - \\
\hline $\begin{array}{l}\text { Teloschistes exilis } \\
\text { (Michx.) Vain. }\end{array}$ & Telos_exi & - & - & - & - & - & 3.80 & 2.70 & - & - \\
\hline $\begin{array}{l}\text { Teloschistes flavicans } \\
\text { (Sw.) Norman }\end{array}$ & Telos_flav & - & - & - & - & - & 12.10 & 3.80 & 0.10 & - \\
\hline Usnea sp. & Usn_sp & - & - & - & - & 1.00 & 1.50 & 1.50 & & 0.20 \\
\hline Usnea sp. 1 & Usn_sp1 & - & - & - & - & - & 1.10 & 0.80 & 30.00 & - \\
\hline Usnea sp. 2 & Usn_sp2 & - & - & - & - & - & - & 0.60 & 0.20 & - \\
\hline Species richness & & 5 & 4 & 8 & 7 & 7 & 12 & 18 & 20 & 23 \\
\hline
\end{tabular}

\section{References}

1. Bell, M.L.; Cifuentes, L.A.; Davis, D.; Cushing, E.; Telles, A.G.; Gouveia, N. Environmental health indicators and a case study of air pollution in Latin American cities. Environ. Res. 2011, 111, 57-66. [CrossRef] [PubMed]

2. Cevallos, V.; Diaz, V.; Sirois, C. Particulate matter air pollution from the city of Quito, Ecuador, activates inflammatory signaling pathways in vitro. Innate Immun. 2017, 23, 392-400. [CrossRef] [PubMed]

3. Alexandrino, K.; Viteri, F.; Rybarczyk, Y.; Andino, J.E.G.; Zalakeviciute, R. Biomonitoring of metal levels in urban areas with different vehicular traffic intensity by using Araucaria heterophylla needles. Ecol. Indic. 2020, 117, 106701. [CrossRef] 
4. Madaniyazi, L.; Xerxes, S. Outdoor air pollution and the onset and exacerbation of asthma. Chronic. Dis. Transl. Med. 2021, 7, 100-106. [CrossRef] [PubMed]

5. Rodriguez, J.; Weller, S.; Wannaz, E.; Klumpp, A.; Pignata, M. Air quality biomonitoring in agricultural áreas narby to urban and industrial emission sources in Córdoba province, Argentina, employing the bioindicator Tillandsia capillaris. Ecol. Indic. 2011, 1, 1673-1680. [CrossRef]

6. Sanchez, A. Biomonitoring potential of five sympatric Tillandsia species for evaluating urban metal pollution $(\mathrm{Cd}, \mathrm{Hg}$ and $\mathrm{Pb})$. Atmos. Environ. 2016, 131, 352-359. [CrossRef]

7. Jacome, H.; King, K. Estudios Industriales de la Micro, Pequeña y Mediana Empresa FLACSO; Ministerio de Industrias y Productividad (MIPRO): Quito, Ecuador, 2013.

8. Villacís, M. Valoración de la Campaña de Monitoreo Pasivo de Gases en la Ciudad de Ambato para el Diseño del Sistema de Calidad de Aire de la Ciudad 2013-2014. Master's Thesis, Universidad Internacional SEK, Quito, Ecuador, 2015.

9. Salazar, R. Valoración Ecológica Ambiental del Parque Provincial de la Familia de la Parroquia Ambatillo del Cantón Ambato. Master's Thesis, Universidad Técnica de Ambato, Quito, Ecuador, 2017.

10. Conti, M.E.; Cecchetti, G. Biological monitoring: Lichens as bioindicators of air pollution assessment-A review. Environ Pollut. 2001, 114, 471-492. [CrossRef]

11. Rubiano, L. Delimitación de áreas de isocontaminación en Cali y Medellín utilizando líquenes como bioindicadores. Pérez Arbelaezia 1987, 1, 7-41.

12. Sim-Siam, M.; Carvalho, P.; Sérgio, C. Cryptogamic epiphytes as indicators of air quality around an industrial complex in the Tagus valley, Portugal. Factor analysis and environmental variables. Cryptogam. Bryol. 2000, 21, 153-170. [CrossRef]

13. Friedel, A.; Müller, F. Bryophytes and lichens as indicators for changes of air pollution in the Serrahn Natural Forest Reserve (Mueritz National Park). Herzogia 2004, 17, 279-286.

14. Santoni, C.; Lijteroff, R. Evaluación de la calidad del aire mediante el uso de bioindicadores en la provincia de San Luis, Argentina. Rev. Int. Contam. Ambient. 2006, 22, 49-58.

15. Das, P.; Joshi, S.; Rout, J.; Upreti, D.K. Lichen diversity for environmental stress study: Application of index of atmospheric purity (IAP) and mapping around a paper mill in Barak Valley, Assam, northeast India. Trop. Ecol. 2013, 54, 355-364.

16. Simijaca, D.; Vargas, D.; Morales, M. Uso de organismos vegetales no vasculares como indicadores de contaminación atmosférica urbana (Tunja, Boyacá, Colombia). Acta Biol. Colomb. 2014, 9, 221-232. [CrossRef]

17. Munzi, S.; Correia, O.; Silva, P.; Lopes, N.; Freitas, C.; Branquinho, C.; Pinho, P. Lichens as ecological indicators in urban areas: Beyond the effects of pollutants. J. Appl. Ecol. 2014, 51, 1750-1757. [CrossRef]

18. Escandón, D.D.; Medina, E.S.; Luecking, R.; Sopkin, P.A.S. Corticolous lichens as environmental indicators of natural sulphur emissions near the sulphur mine El Vinagre (Cauca, Colombia). Lichenologist 2016, 48, 147-159. [CrossRef]

19. Abas, A. A systematic review on biomonitoring using lichen as the biological indicator: A decade of practices, progress and challenges. Ecol. Indic. 2021, 121, 107197. [CrossRef]

20. Asta, J.; Erhardt, W.; Ferretti, M.; Fornasier, F.; Kirschbaum, U.; Nimis, P.L.; Wirth, V. Mapping lichen diversity as an indicator of environmental quality. In Monitoring with Lichens-Monitoring Lichens; Springer: Dordrecht, The Netherlands, 2002 ; pp. $273-279$.

21. Hawksworth, D.L.; Iturriaga, T.; Crespo, A. Líquenes como bioindicadores inmediatos de contaminación y cambios medioambientales en los trópicos. Rev. Iberoam. Micol. 2005, 22, 71-82. [CrossRef]

22. Gombert, A.; Seaward, M.R.D. Lichens and tobacco plants as complementary biomonitors of air pollution in the Grenoble area (Isère, southeast France). Ecol. Indic. 2006, 429-443. [CrossRef]

23. Poličnik, H.; Simončič, P.; Batič, F. Monitoring air quality with lichens: A comparison between mapping in forest sites and in open areas. Environ. Pollut. 2008, 151, 395-400. [CrossRef]

24. Jayalal, U.; Oh, S.O.; Park, J.S.; Sung, J.H.; Kim, S.H.; Hur, J.S. Evaluation of air quality using lichens in three different types of forest in Korea. For. Sci. Technol. 2016, 12, 1-8. [CrossRef]

25. Tanona, M.; Czarnota, P. Index of Atmospheric Purity reflects the ecological conditions better than the environmental pollution in the Carpathian forests. J. Mt. Sci. 2020, 17, 2691-2706. [CrossRef]

26. Käffer, M.; Azevedo, S.; Alves, C.; Camejo, V.; Fachel, J.; Ferrão, V. Corticolous lichens as environmental indicators in urban areas in southern Brazil. Ecol. Indic. 2011, 11, 1319-1332. [CrossRef]

27. Correa-Ochoa, M.A.; Vélez-Monsalve, L.C.; Saldarriaga-Molina, J.C.; Jaramillo-Ciro, M.M. Evaluation of the Index of Atmospheric Purity in an American tropical valley through the sampling of corticulous lichens in different phorophyte species. Ecol. Indic. 2020, 115, 106355. [CrossRef]

28. Canseco, A.; Anze, R.; Franken, M. Comunidades de líquenes: Indicadores de la calidad del aire en la ciudad de La Paz, Bolivia. Acta Nova 2006, 3, 286-307.

29. Anze, R.; Franken, M.; Zaballa, M.; Pinto, M.; Zeballos, G.; Cuadros, M.; Canseco, A.; De La Rocha, A.; Estellano, V.; Del Granado, S. Bioindicadores en la detección de la contaminación atmosférica en Bolivia. Rev. Virtual REDESMA 2007, 1, 54-74.

30. Lijteroff, R.; Lima, L.; Prieri, B. Uso de líquenes como bioindicadores de contaminación atmosférica en la ciudad de San Luis, Argentina. Rev. Int. Contam. Ambient. 2009, 25, 111-120.

31. Estrabou, C.; Filippini, E.; Soria, J.; Schelotto, G.; Rodriguez, J. Air quality monitoring system using lichens as bioindicators in Central Argentina. Environ. Monit. Assess. 2011, 182, 375-383. [CrossRef] 
32. Ochoa-Jimenez, D.; Cueva, A.; Prieto, M.; Aragón, G.; Benítez, Á. Cambios en la composición de líquenes epífitos relacionados con la calidad del aire en la ciudad de Loja (Ecuador). Caldasia 2015, 37, 333-343. [CrossRef]

33. Aspiazu, J.; Cervantes, J.; Ramírez, J.; López, R.; Ramos, R.; Muñoz, P.; Villaseñor, P. Temporal and spatial trends studied by lichen analysis: Atmospheric deposition of trace elements in Mexico. Rev. Mex. Fís. 2008, 53, 87-96.

34. Neurohr, E.; Monge-Nájera, J.; González, M.I. Air pollution in a tropical city: The relationship between wind direction, season and lichen bio-indicators in San José, Costa Rica. Rev. Biol. Trop. 2011, 59, 899-905.

35. Gómez, H.; Fernández, R.; Benzo, Z.; Galarraga, F.; Hernández, J.; Roschman, G. Líquenes como biomonitores de la contaminación atmosférica por hidrocarburos aromáticos policíclicos (HAP): Revisión. Rev. Fac. Ing. UCV 2015, 28, 45-58.

36. Quispe, K.; Ñque, M.; Chuquilin, E. Líquenes como bioindicadores de la calidad del aire en la ciudad de Tingo María. RevIA 2013, 3, 99-104.

37. Benítez, Á.; Medina, J.; Vásquez, C.; Loaiza, T.; Luzuriaga, Y.; Calva, J. Lichens and bromeliads as bioindicators of heavy metal deposition in Ecuador. Diversity 2019, 11, 28. [CrossRef]

38. Benítez, Á.; Armijos, L.; Calva, J. Monitoring Air Quality with Transplanted Bryophytes in a Neotropical Andean City. Life 2021, 11, 821. [CrossRef]

39. Churchill, S.P.; Linares, E.L. Prodomus Bryologie Novo Granatensis. Introducción a la Flora de Musgos de Colombia: Tomos I y II; Instituto de Ciencias Naturales, Facultad de Ciencias, Universidad Nacional de Colombia: Bogotá, Colombia, 1995.

40. Gradstein, S.R.; Churchill, S.P.; Salazar, N. Guide to the Bryophytes of Tropical America; Memoirs of the New York Botanical Garden; New York Botanical Garden Press: Bronx, NY, USA, 2001; Volume 86, pp. 1-577.

41. Gradstein, S.R. The Liverworts and Hornworts of Colombia and Ecuador; New York Botanical Garden: Bronx, NY, USA, 2020.

42. Brodo, I.M.; Sharnoff, S.D.; Sharnoff, S. Lichens of North America; Yale University Press: New Haven, AZ, USA; London, UK, 2001.

43. Nash, T.H.; Ryan, B.D.; Gries, C.; Bungartz, F. Lichen Flora of the Greater Sonoran Desert Region; Lichens Unlimited: Tempe, AZ, USA, 2002; Volume 1.

44. Nash, T.H.; Ryan, B.D.; Diederich, P.; Gries, C.; Bungartz, F. Lichen Flora of the Greater Sonoran Desert Region; Lichens Unlimited: Tempe, AZ, USA, 2004; Volume 2.

45. Nash, T.H.; Gries, C.; Bungartz, F. Lichen Flora of the Greater Sonoran Desert Region; Lichens Unlimited: Tempe, AZ, USA, 2007; Volume 3.

46. Zuur, A.F.; Ieno, E.N.; Smith, G.M. Analysing Ecological Data; Statistics for Biology and Health; Springer: New York, NY, USA, 2007.

47. R Team Development Core Team. R: A Language and Environment for Statistical Computing; R Foundation for Statistical Computing: Vienna, Austria, 2020.

48. Oksanen, J.; Blanchet, F.G.; Friendly, M.; Kindt, R.; Legendre, P.; Mcglinn, D.; Minchin, P.R.; O’hara, R.B.; Simpson, G.L.; Solymos, P.; et al. Package "vegan". Community Ecol. Package 2013, 2, 1-295. Available online: https://cran.r-project.org/web/ packages/vegan/ (accessed on 17 January 2019).

49. Rubiano, L. Monitoria de áreas de isocontaminación en la región de influencia de la Central Termoeléctrica Martín del Corral utilizando líquenes como bíoindicadores. Perez Arbelaezia 2002, 13, 91-104.

50. Méndez, V.; Monge, J. El uso de líquenes como biomonitores para evaluar el estado de la contaminación atmosférica a nivel mundial. Biocenosis 2011, 25, 51-67.

51. Monge-Nájera, J.; Gonzales, M.; Rivas, M. Un nuevo método para evaluar la contaminación del aire utilizando líquenes como bioindicadores. Rev. Biol. Trop. 2002, 50, 321-325.

52. Koch, N.M.; Matos, P.; Branquinho, C.; Pinho, P.; Lucheta, F.; de Azevedo Martins, S.M.; Vargas, V.M.F. Selecting lichen functional traits as ecological indicators of the effects of urban environment. Sci. Total Environ. 2019, 654, 705-713. [CrossRef]

53. Chuquimarca, L.; Gaona, F.P.; Iñiguez-Armijos, C.; Benítez, Á. Lichen responses to disturbance: Clues for biomonitoring land-use effects on riparian Andean ecosystems. Diversity 2019, 11, 73. [CrossRef]

54. Lucheta, F.; Koch, N.M.; Käffer, M.I.; Riegel, R.P.; de Azevedo Martins, S.M.; Schmitt, J.L. Lichens as indicators of environmental quality in southern Brazil: An integrative approach based on community composition and functional parameters. Ecol. Indic. 2019, 107, 105587. [CrossRef] 